\title{
Pheochromocytoma and Paraganglioma Clinical TNM Finding v8
}

National Cancer Institute

\section{Source}

National Cancer Institute. Pheochromocytoma and Paraganglioma Clinical TNM Finding

v8. NCI Thesaurus. Code C141106.

A clinical finding about one or more characteristics of pheochromocytoma and paraganglioma, following the rules of the TNM AJCC V8 classification system. 